\title{
The pronominal coding of the patient in reflexive indefinite agent constructions in Peninsular Spanish
}

\author{
CARLOTA DE BENITO MORENO
}

\section{Abstract}

This paper is concerned with the pronominalization of the patient in reflexive passives and reflexive impersonals in Peninsular Spanish. It is commonly agreed that only human patients can pronominalize in these contexts in Standard Peninsular Spanish. However, some varieties show full pronominalization of non-human patients. This paper aims to describe the geographical distribution of this pronominalization in Peninsular Spanish, together with the evolution of this phenomenon. Dialectal data allow describing the evolution of linguistic phenomena by means of investigating their geographical spreading in different contexts. The data contained in this paper show that the pronominalization of the patient in reflexive indefinite agent constructions (namely, reflexive passives and reflexive impersonals) is related to the animacy hierarchy, connecting this phenomenon with the more general category of agreement.

Keywords

Pronominalization, reflexive passive, reflexive impersonal

\section{Introduction}

This paper aims to investigate the geographical distribution of the pronominalization of the patient in reflexive passives and reflexive impersonals in Peninsular Spanish. ${ }^{1}$ In Standard Peninsular Spanish, the

\footnotetext{
${ }^{1}$ Since both constructions are clearly related, the term "reflexive indefinite agent construction" will be used to refer to both of them when their differences are not relevant.
} 
patient can only be replaced by an unstressed pronoun in these constructions when it is [+human] and [+definite] (1) (RAE 2009, de Mello 2005). ${ }^{2}$ However, it appears that the pronominalization of the patient is less restricted in some varieties, a phenomenon I will call here "extended pronominalization" (2) (Studerus 1984, Fernández-Ordóñez 1999, de Mello 2005). This paper analyses the geographical and semantic distribution of the extended pronominalization in Peninsular Spanish.

(1) a. $\left[\mathrm{Juan}_{\mathrm{i}}\right] \mathrm{Se} \quad \mathrm{l}_{\mathrm{i}}$ vio en la plaza [John] REFL him.DAT saw.3SG in the square [John] 'He was seen in the square'

b. [muchos coches $\mathrm{i}$ ] Se $\varnothing_{\mathrm{i}}$ vieron en la plaza [many cars] REFL saw.3PL in the square [a lot of cars] 'They were seen in the square'

(2) Villaverde-Mogina (Burgos)

a. [la gallina $\mathrm{a}_{\mathrm{i}}$ ] Se $\mathrm{la}_{\mathrm{i}}$ echaba con huevos que tengan gallo [the hen] REFL her.ACC threw.3SG with eggs that have rooster [the hen] 'They put her taking care of fertilized eggs'

b. [tripas de cerdo $\mathrm{o}_{\mathrm{i}}$ ] Se las $\mathrm{la}_{\mathrm{i}}$ deslava un poco [intestine of pig] REFL them.ACC cleans a little [the pig's intestine] 'It was cleaned a little'

c. [el queso ${ }_{i}$ Se $\quad l_{i}$ tiene un día por lo menos [the cheese] REFL it.ACC has one day for the least [the cheese] 'It was kept one day at least'

In section 2, a more detailed explanation of the phenomenon is presented, together with a hypothesis of the evolution of the extended pronominalization. Section 3 explains the characteristics of the corpus used. In section 4, the data, presented in dialectal maps, are analysed, together with other related phenomena. Section 5 briefly sums up the conclusions obtained.

\section{The extended pronominalization}

The extended pronominalization is a complex phenomenon that interacts with several other areas of Spanish grammar. First, the fact that the pronominalization is only possible with [+human] and [+definite] patients in Standard Spanish is reminiscent of the differential object marking mechanism: in Standard Spanish the participant in the accusative is preceded

${ }^{2}$ In the active construction, unstressed pronouns may replace definite noun phrases of any kind. 
by the preposition $a$ when it shows these two features. ${ }^{3}$ Hence, we may say that the pronominalization of the patient in the reflexive indefinite agent constructions works also as a differential object marking mechanism, since it marks differently [+human, +definite] patients and [-human] or [-definite] patients. $^{4}$

The extended pronominalization is also related to the distinction between reflexive passive and reflexive impersonal, both marked with the reflexive pronoun se. In Standard Spanish, reflexive passives have a transitive verb that agrees with the patient (3) (RAE 2009, Mendikoetxea 1999), while reflexive impersonals admit both intransitive verbs (4a) and transitive verbs whose patient is preceded by the preposition $a(4 \mathrm{~b})$, which always occur in the third person singular (RAE 2009, Mendikoetxea 1999). Nevertheless, some varieties show a somehow different situation. In some areas, there is a tendency to freeze transitive verb morphology in the singular even when the patient is not marked with the preposition; that is to say, when it is [-animate] or [-definite] (5) (RAE 2009, de Benito in revision).
a. Se
vende una
casa
REFL Sell.3SG one
house

'A house is sold here'
b. Se venden casas
REFL sell.3PL houses
'Houses are sold here'
(4) a. Se vive muy bien aquí
REFL lives very well here

'One lives very happy here'
b. Se castigó a los ladrones
REFL punished.3SG to the thieves
'The thieves were punished'
(5) Se necesita ordenadores
REFL needs computers
'Computers are needed'

Altogether, this means that in Standard Spanish, pronominalizing the patient is only possible with reflexive impersonals, and impossible with

\footnotetext{
${ }^{3}$ Animacy and definiteness are the two most influential factors to determine the presence of the preposition. However, some other factors, such as the lexical nature of the verb, the existence of an object-oriented secondary predication, the postverbal position of the object, or clitic doubling, may interact with them, favouring the presence of the preposition in other contexts (Laca 2006).

${ }^{4}$ I thank Inés Fernández-Ordóñez for this observation.
} 
reflexive passives. In the varieties where the pronominalization is less restricted, pronominalization only appears in reflexive impersonal constructions (RAE 2009), since the patient is replaced by an object pronoun, which does not trigger verbal agreement (6).
a. Se ve
al
niño $>\mathrm{Se}$
le ve
REFL see.3SG to-the boy $>$ REFL him see.3SG
'The boy is seen' $>$ 'He is seen'
b. Se deslavan las tripas del cerdo
REFL clean.3PL the intestines of.the pig
'The intestine of the pig are cleaned'
c. Se las deslava $/ * \mathrm{Se}$ las deslavan
REFL them cleans / REFL them clean.3PL
'They are cleaned'

Fernández-Ordóñez (1999) suggests that the extended patient pronominalization area coincides with that of the referential pronoun system (a northern area). In this area, the etymologically case-based pronominal system $(l o(s)$ for masculine accusative, $l a(s)$ for feminine accusative and $l e(s)$ for dative) is no longer at work, and it has been replaced by a system based on the semantic features of the referent: $l e(s)$ for masculine count nouns, $l a(s)$ for feminine count nouns and $l o$ for mass nouns. The relation between the so-called referential pronominal system and the extended pronominalization may be explained by the fact that datives appear to show no restrictions to pronominalize (7) in indefinite agent reflexive constructions in any Spanish variety (Fernández Soriano 1993, Mendikoetxea 1999). As a consequence of the loss of case distinction in this area, the case restriction may have also disappeared in pronominalization. ${ }^{5}$ In this area, there also seems to be a tendency to use unstressed pronouns where other varieties (including Standard Spanish) prefer null pronouns, that is to say, to replace non-definite objects (8). Although the extended pronominalization studied here applies mainly to definite pronouns (cf. below), these phenomena are clearly related.

\section{(7) Almajano (Soria)}

[la pulpa] Se le echaba también a los cochinos [the peel] REFL him threw also to the pigs [the peel] 'It was thrown to the pigs'

\footnotetext{
${ }^{5}$ However, the extended pronominalization appears to be relatively common in Argentina and Chile, where the etymological pronominal system persists (Fernández-Ordóñez 1999, RAE 2009). Fernández-Ordóñez relates this fact to the tendency that these varieties show to transitivize originally intransitive constructions.
} 


\section{(8) Moraleja de Cuéllar (Segovia) \\ $\mathrm{Y}$ le hay, alcalde también \\ and him have.3SG mayor too}

'And there is one, a mayor too'

Regarding the diachronic development of the extended pronominalization, most scholars agree that the pronominalization of the patient in reflexive indefinite agent constructions appeared in the 16th century with [+human] and [+definite] patients, always marked with the (etymologically dative) pronoun $l e$. The (etymologically accusative) feminine pronoun la would not have started marking feminine patients until the 18th century (Santiago 1975). There has been a lot of discussion about the status of the (etymologically accusative) pronoun $l o$ in this construction, since it was not documented until relatively late and Peninsular Standard Spanish rejects it (in Argentina and Chile, on the other hand, it is the most common solution to refer to masculine patients, Fernández-Ordóñez 1999, RAE 2009). Despite the fact that some scholars have claimed that its combination with the reflexive indefinite construction is ungrammatical (Fernández Lagunilla 1975), Fernández-Ordóñez (1999) has shown that lo is often used to replace uncountable patients in these constructions in the referential area.

This paper will not address the question about which pronoun is used, but it will be specially concerned with the evolution of the extended pronominalization through the different kinds of patients. The hypothesis presented here is that both the animacy hierarchy and the definiteness scale would have determined this evolution.

There are several reasons that lead to this hypothesis. As noted above, the pronominalization in this construction appeared first with [+human] and [+definite] patients. These are precisely the features on the top of the animacy hierarchy and the definiteness scale, respectively. Secondly, considering the data on how the construction spread through the different pronouns in the light of the referential pronoun system, it seems that it followed the animacy hierarchy. It started replacing count nouns (with no gender distinction at first, using only le, but this distinction came later, with la for the feminine) and it ended replacing mass nouns (with lo). Finally, both the animacy hierarchy and the definiteness scale have proved to be determinant in other related phenomena, such as differential object marking (Laca 2006), clitic doubling (Schwenter 2006) and the distinction passive-impersonal reflexive (de Benito in revision). As it will be seen below, these phenomena are ultimately related to the more general category of agreement and case-marking, both deeply connected with animacy and definiteness.

The animacy hierarchy, in (9) below, is an implicational hierarchy that ranks noun phrases according to their animacy features (that is to say, grading them according to how sentient they are). The top of this hierarchy usually consists of personal pronouns (1st person, 2nd person $>3$ rd person) 
(Croft 1988, Corbett 2006). However, in this paper, since what is being investigated is the possibility of pronominalizing the patient, only the animacy proper hierarchy will be used, in order to rank the referents of the patients. The inanimate range is split here in two different categories: count and mass, since this distinction has proved to be determinant in the choice of the pronouns in the Northwest of Spain (Fernández-Ordóñez 1999).

\section{(9) Human $>$ Animate $>$ Count (inanimate) $>$ Mass (inanimate) ${ }^{6}$}

The definiteness scale, in (10) below, is an implicational scale that ranks the participants of an event according to how "identifiable or accessible to the hearer" they are (Givón 2001). ${ }^{7}$ Three different categories have been established in this paper: definite noun phrases (marked with definite determiners, such as articles: el cerdo 'the pig'), indefinite noun phrases (marked with indefinite determiners, such as quantifiers: muchos cerdos 'a lot of pigs') and bare nouns (with no determiners whatsoever, usually in the plural: cerdos 'pigs'). The last one would be the most resistant category to pronominalization. However, it is important to note that definiteness can be only examined when the patient occurs explicitly, as a noun phrase, not only as a (full or null) pronoun. That is to say, only when the patient is in the topic (left-dislocated) position or when the reflexive indefinite agent construction is in a relative clause with an explicit antecedent, the definiteness features can be observed. On the contrary, animacy features can be analysed when the patient is not expressed in the sentence studied, thanks to the context where it is uttered.

(10) Definite $>$ Universal quantifier $>$ Indefinite $>$ Bare nouns

${ }^{6}$ It is well known that languages differ in how animate they consider some referents. In the data analysed here, saints and Christ images were classified together with other human referents, since it was clear that they were being treated grammatically as such (not only as regards pronominalization, but also the use of the preposition $a$ when they are direct objects, for example). Only animals (not plants) were included in the animate category. On the bottom of the scale, a new category labelled as "event" could be added, referring to clausal patients. "Clausal patients" is a relatively strange concept, since events or clauses can hardly be understood as "affected by the verb's event". It refers to the clausal object in the equivalent active clause or to the objects of verbs such as hacer 'to do, make', which are usually whole events and not mere participants. This would be the most resistant category to pronominalization, confirmed by the fact that, in the corpus considered here, no examples of event full pronominalization in indefinite agent constructions were found.

${ }^{7}$ Definiteness is deeply related to the concept of reference (Croft 1988). Despite the fact that in Spanish definite noun phrases may code generic reference, in this paper, only definiteness (in its formal correlate, determination, Rodrígez Molina 2010) has been used to classify the data, since the classification of the patients as referential, indefinite or generic is a somehow complicated task. 


\section{The corpus}

The data used here comes from the Oral and Audible Corpus of Rural Spanish (COSER). This corpus consists of (around one hour long) semi-open interviews to rural and elderly informants. The informants are asked about old traditions, topic that extraordinarily favours the appearance of indefinite agent constructions. However, the frequency of some of the contexts that affect this research is relatively low, and the data are scarce. Firstly, indefinite subject reflexive constructions with human patients are relatively uncommon, since speakers tend to personalize when asked about traditions concerning human participants (such as weddings or balls), speaking about their own experience. Reflexive indefinite agent constructions with topical left dislocated patients or within relative clauses are less frequent too, as left dislocation and relativization are both low frequency phenomena. Therefore, the data in this context will only be able to show some tendencies, rather than clear-cut conclusions.

The data have been collected from three to five villages in 29 Spanish provinces. ${ }^{8}$ The analysed corpus was formed by around one million words.

\section{The data}

\subsection{Affected area}

Since it is commonly acknowledged that pronominalization of human patients is acceptable in every Spanish variety, map I shows where pronominalization with other patients was attested in the corpus. This area, located in the Northwest of the Spanish speaking area of the Peninsula, includes the Basque Country, the West of Navarra, the North of La Rioja and Burgos, the East of León and Salamanca, Palencia, Valladolid, Segovia, Ávila, the West of Toledo, the North of Ciudad Real and the Southeast of Caceres.

This area coincides to a great extent with the referential pronominal system area, illustrated in map II with the label "West Castilian paradigm" (Fernández-Ordóñez in press). It also includes the Basque Spanish paradigm, which is not surprising, since le is also used for human accusatives in this paradigm:

${ }^{8}$ The bilingual areas Galicia, Catalonia and Valencia together with the South of Spain (Andalucía and Murcia) have not been interviewed for the COSER yet. Some areas that may present the extended pronominalization (such as Asturias, most of Cantabria and Guadalajara) are currently being revised for the COSER, so data are not available yet. 
Map I: Extended pronominalization area

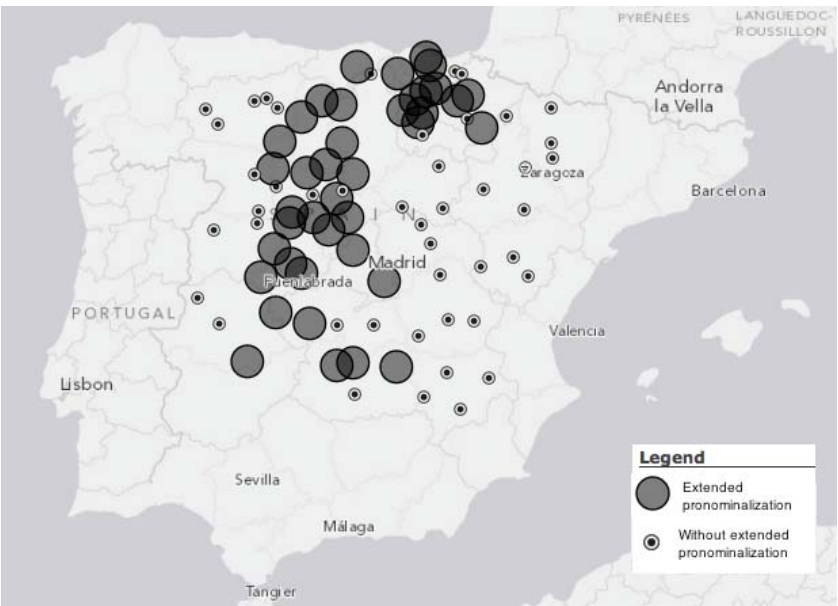

Map II: Referential pronominal system (Fernández-Ordóñez in press)

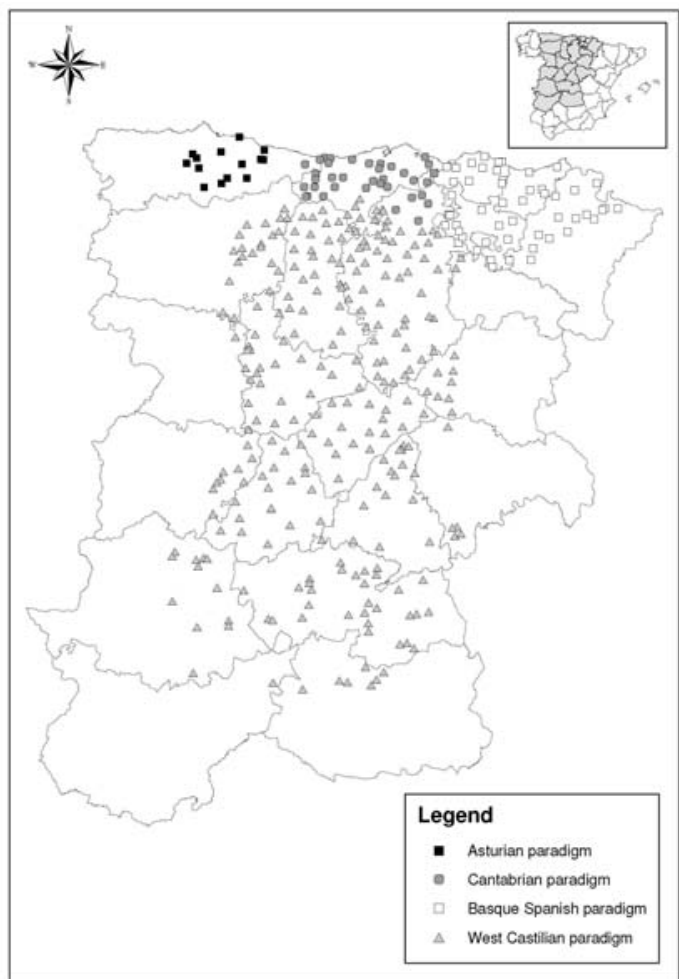




\subsection{Animacy hierarchy}

Maps III, IV and V show the geographical distribution of the extended pronominalization attending to the patient animacy features. Map III represents pronominalization with (non-human) animate patients; map IV with inanimate countable patients, and map $\mathrm{V}$ with inanimate mass patients.

Map III: Extended pronominalization with animate patients

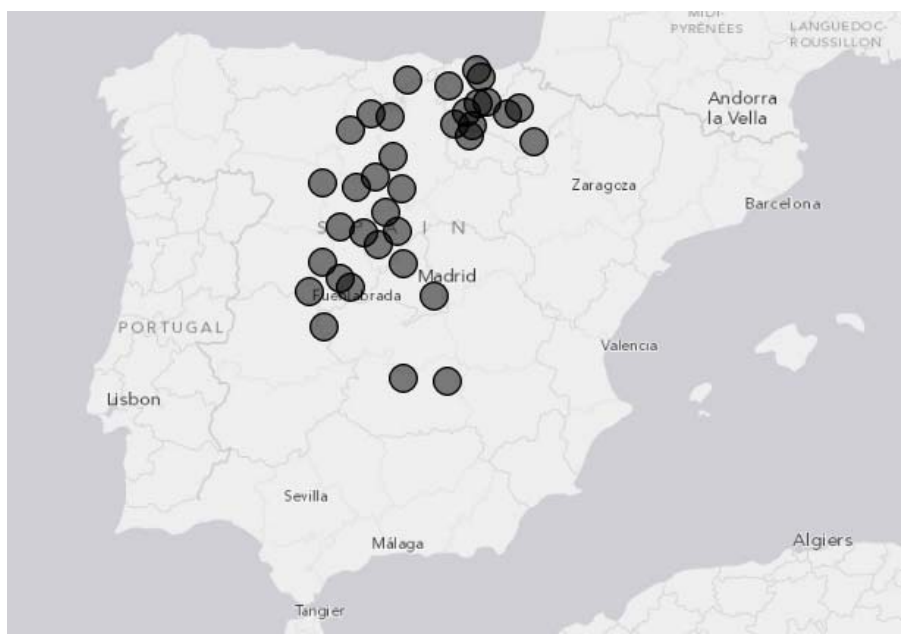

Map IV: Extended pronominalization with countable patients

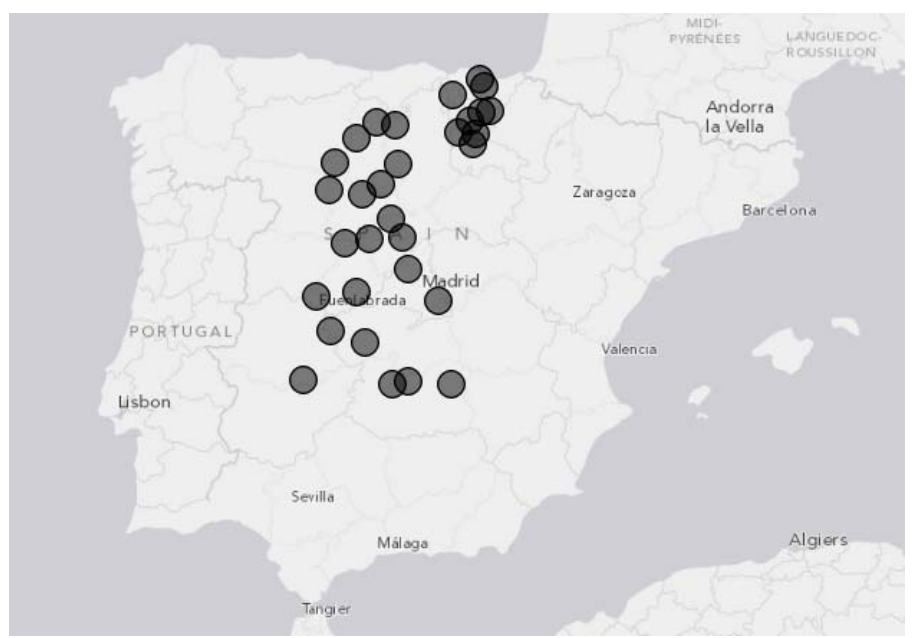


Map V: Extended pronominalization with mass patients

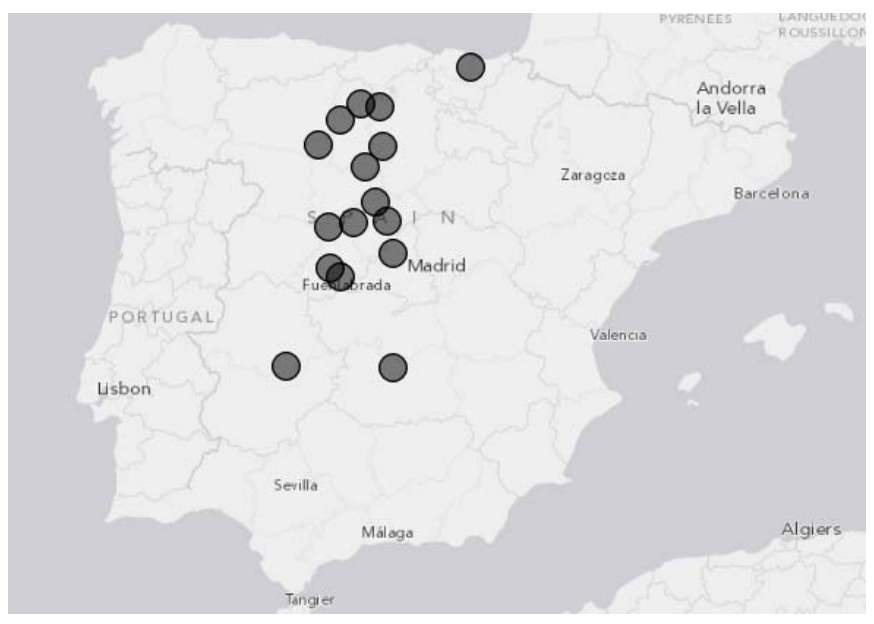

The areas drawn by map III (animate nouns) and IV (count nouns) are rather similar, but map $\mathrm{V}$ clearly shows how pronominalization of mass nouns is much more restricted. In table $\mathrm{I}$, the overall frequency of the extended pronominalization is displayed, with human patients and "event" objects (cf. endnote 6) as well. The data in this table show that the animacy hierarchy is being followed: pronominalization with human patients occurs in $63,46 \%$ of cases and its frequency gradually decreases through the animacy hierarchy, showing that pronominalization is not possible with event objects. Table I also shows that even if the geographical areas of the extended pronominalization with animate and count nouns are similar, it is fairly more frequent with animate nouns.

Table I: Pronominalization frequency: the animacy hierarchy

\begin{tabular}{|r|c|c|c|c|c|}
\hline & Human & Animate & Count noun & Mass noun & Event \\
\hline Full & 33 & 171 & 140 & 44 & 0 \\
pronoun & $63,46 \%$ & $36,93 \%$ & $11,60 \%$ & $4,17 \%$ & $0 \%$ \\
\hline Null & 19 & 292 & 1067 & 1011 & 148 \\
pronoun & $36,54 \%$ & $63,07 \%$ & $88,40 \%$ & $95,83 \%$ & $100 \%$ \\
\hline Total & 52 & 463 & 1207 & 1055 & 148 \\
\hline
\end{tabular}


Moreover, out of the 41 villages that showed the extended pronominalization, the data of 34 of them $(82,93 \%)$ also follow the hierarchy. That is to say, if pronominalization with mass nouns occurs in these villages, pronominalization with count and animate nouns is also attested, and if pronominalization with count nouns is attested in these villages, so it is pronominalization with animate nouns. Out of the other 7 localities, 6 had singularly few data in the range that violates the hierarchy (less than 6 total occurrences), which may be the cause of this apparent violation.

\subsection{Explicit patients}

As noted above, in order to examine the relevance of the definiteness scale, we can only use examples of topical left-dislocated patients (12) or antecedent of relative clause patients (11), since these are the only two contexts where pronominalization of the patient is admitted together with the explicit presence of the patient. These two contexts are significantly less common than the pronominalization of an already mentioned patient, as can be seen in Table II.

\section{(11) Villaverde Mogina, Burgos}

que las que se las deja después para las sabanicas, que son más grasas... that those that REFL them leaves after for the sheets that are more fat 'Those that are left afterwards for the sheets, that have more fat'

(12) Muñoveros, Segovia

Pues esa tela, se la descose so that fabric REFL her unpicks 'So that fabric, you unpick it'

Despite the shortage of the data, a clear tendency may be observed in Table II; namely, pronominalization is clearly disfavoured by the explicit appearance of the patient, either in relative clauses or in clauses showing topic left-dislocation. Pronominalization with topical left-dislocated patients only occurred in 4,34\% of all the topical left-dislocated cases, and it appears to be absolutely exceptional within relative clauses, where it occurred only in one case $(0,57 \%)$.

Hence, it appears that the explicit presence of the patient disfavours the co-appearance of the object pronoun in the reflexive indefinite agent construction. This is understandable within relative clauses, since they always disfavour the pronominalization of the antecedent when it is a patient (RAE 2009). However, this absence of the pronoun is unexpected in topical left-dislocated constructions, since they usually require the presence of a pronoun that doubles the topical participant. A possible explanation for this surprising situation may be the singular status of the patient of reflexive 
indefinite-agent constructions, which shares features both with syntactic subjects (such as triggering verbal agreement in the passive) and syntactic objects (such as being pronominalized by an object pronoun). Subjects in Spanish do not require clitic doubling when they are topics.

Table II: Pronominalization frequency: occurrence of an antecedent

\begin{tabular}{|r|c|c|c|}
\hline & $\begin{array}{c}\text { Without } \\
\text { an explicit antecedent }\end{array}$ & $\begin{array}{c}\text { Topical } \\
\text { left-dislocated }\end{array}$ & $\begin{array}{c}\text { Antecedent } \\
\text { of relative clause }\end{array}$ \\
\hline Full & 355 & 27 & 1 \\
pronoun & $16,83 \%$ & $4,34 \%$ & $0,57 \%$ \\
\hline Null & 1754 & 595 & 174 \\
pronoun & $83,17 \%$ & $95,66 \%$ & $99,43 \%$ \\
\hline Total & 2109 & 622 & 175 \\
\hline
\end{tabular}

Concerning the relevance of the definiteness scale, Table III suggests that pronominalization is only possible in the top of the scale; that is to say, with definite nouns. These are the expected results, according to the hypothesis that the definiteness scale is a relevant underlying factor.

Table III: Pronominalization frequency: the definiteness scale

\begin{tabular}{|c|c|c|c|c|c|c|}
\hline \multirow{2}{*}{} & \multicolumn{2}{|c|}{ Antecedent of relative clause } & \multicolumn{3}{|c|}{ Topical left-dislocated } \\
\cline { 2 - 7 } & $\begin{array}{c}\text { Definite } \\
\mathrm{N}\end{array}$ & Bare N & $\begin{array}{c}\text { Indefinite } \\
\mathrm{N}\end{array}$ & $\begin{array}{c}\text { Definite } \\
\mathrm{N}\end{array}$ & Bare N & $\begin{array}{c}\text { Indefinite } \\
\mathrm{N}\end{array}$ \\
\hline Full & 1 & 0 & 0 & 27 & 0 & 0 \\
pronoun & $0,9 \%$ & $0 \%$ & $0 \%$ & $4,7 \%$ & $0 \%$ & $0 \%$ \\
\hline Null & 110 & 25 & 39 & 547 & 31 & 17 \\
pronoun & $99,1 \%$ & $100 \%$ & $100 \%$ & $95,3 \%$ & $100 \%$ & $100 \%$ \\
\hline Total & 111 & 25 & 39 & 574 & 31 & 17 \\
\hline
\end{tabular}

\subsection{What agreement has to say}

There is an ongoing discussion about the status of the Spanish pronominal clitics in the literature (cf. Fernández Soriano 1993 and the references therein). Some authors consider that these clitics are not independent words 
anymore and that they have grammaticalised into verbal affixes. In this subsection, some of the arguments in which this hypothesis relies will be briefly described and they will be linked to the phenomenon studied here, through the notion of agreement.

Clitics in Spanish seem to behave sometimes as verbal affixes and they have been seen as an objective conjugation. There are several arguments that support this hypothesis (Fernández Soriano 1993). On the one hand, clitic pronouns are unstressed and they depend phonologically on the verb. This close relationship with the verb can be further observed in the fact that they may alter the form of the verb (for example, the imperative lavad 'wash' together with the 2PL pronoun os loses the final $-d$ and becomes lavaos 'wash yourselves').

There are also morphological reasons to believe that clitic pronouns in Spanish behave like agreement affixes. First of all, when two clitics appear in the same sentence, they must be together, not admitting other elements between them. Some dialectal phenomena show how this fusion has morphological consequences. For example, in Eastern Spanish, a sort of 'inflected infinitives' are found (13), where the plural agreement marker $-n$ follows the reflexive clitic se in infinitives, in order to mark that the subject is plural. This demonstrates that the union between the verb and the clitic is felt as extremely strong. In the same direction, the se les/se los construction is found in some areas (Eastern Spanish and Río de la Plata, respectively), where the accusative clitic occurs in the plural to mark that not itself, but the dative, which lacks number distinction when precedes the accusative clitic, is in the plural (14). These phenomena suggest that the clitics show a high degree of morphological fusion both with the verb and within themselves.

(13) San Andrés del Rey, Guadalajara

tenía-n que hacer la comida y luego ir-se-n al had-3PL that make the food and after go.INF-REFL-3PL to-the campo countryside

'They had to prepare the food, and after that, go the countryside'

(14) Perales de Alfambra, Teruel

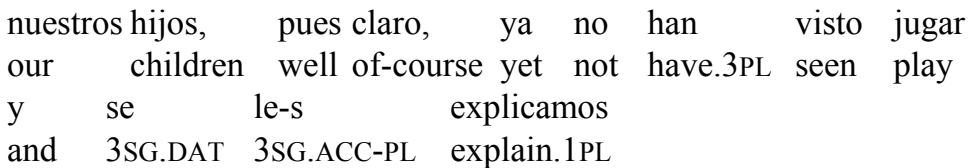

'Well, of course, our children haven't seen us play so we explain it to them'

A phenomenon that has been widely studied is clitic doubling. Clitic pronouns often co-appear with the co-referential full nominal phrase in a 
clause. This is especially true for the dative clitic, which can be doubled in every variety in any case (15). The accusative clitic doubles compulsorily pronominal patients and left-dislocated patients, as it was said above. In some varieties (like Rioplatense or Basque Spanish), it may reduplicate other kind of patients too (16). This, together with the fact that the stressed pronoun is usually felt as emphatic (paralleling the situation with the subject pronoun and the verbal subjective affixes), suggests that the unstressed pronouns in Spanish are, at least sometimes, mere agreement affixes.

\section{Pedruzo (Condado de Treviño), Burgos}

luego se lo echas a los caracoles

after 3.DAT it.ACC throw.2SG to the snails

'After that, you throw it into the snails'

(16) (from RAE 2009)

Lo sigue usando el mismo auto

it.ACC keeps using the same car

'He keeps using the same car'

When two clitics appear together in the same sentence, their relative order follows strict rules that take into account both person and case distinctions, forming clusters with a specific distribution. Fernández Soriano (1993) notes that this behaviour is rather affix-like, separating them from independent words. The extended pronominalization studied here offers the possibility of adding to this list a new behaviour criterion, which also suggests that clitics in Spanish show affix properties.

It is well known that object agreement follows the animacy hierarchy and the definiteness scale in many languages. In Croft's (1990: 129) words, "[D]irect objects that are the most animate and definite are those that the verb will most likely agree with typologically". The fact that the extended pronominalization studied here follows both hierarchies also aligns Spanish clitics behaviour with agreement affixes, like the phenomena described above.

Furthermore, the animacy hierarchy may be seen as a determinant factor in the grammaticalization of clitic pronouns into affixes in Spanish. It seems that the process of becoming verbal affixes is almost completed with clitics referring to definite humans, whereas clitics referring to other kind of patients are further away from completing this process. This is not only derived from the data in this paper, but also by the fact that datives and pronominal accusatives are those compulsorily doubled by a clitic. Since datives are typically human, this suggests that the determinant factor is not the grammatical role of the verbal argument (accusative or dative), but the semantic characteristics of the referent. 


\section{Conclusion}

In this paper, I have shown the geographical distribution of the pronominalization of the patient in reflexive indefinite agent constructions with [-human] patients, which occupies a large area of the Northwest of Spain. As expected, according to the typological theories about agreement (Croft 1988, Corbett 2006), the data analysed here show that both the geographical extension of the phenomenon and its overall frequency of use is especially connected with the animacy hierarchy. As regards the definiteness of the patient, despite the relative scarcity of the data, a clear tendency was observed, suggesting that non-definite patients disfavour the full pronominalization. However, the precedence of the explicit patient, also a relevant factor in agreement phenomena (Rodríguez Molina 2010) seems to disfavour it. I have hypothesized here that this may be due to the ambivalent syntactic nature of the patient in reflexive indefinite agent constructions, which shares features both with subjects and objects. Lastly, concerning the more general category of agreement and the importance of both the animacy hierarchy and the definiteness scale to determine agreement phenomena, it was proposed here that Spanish clitics are very close to converting into agreement affixes when their referents are on the top of both hierarchies.

\section{Acknowledgements}

I would like to thank Inés Fernández-Ordóñez, Javier Rodríguez Molina and Pen Neves for their comments to a previous version of this paper.

\section{References}

Corbett, G. (2006) Agreement. Cambridge: Cambridge University Press.

Croft, W. (1988) Agreement vs. case marking and direct objects. In Agreement in natural languages (M. Barlow \& C. A. Ferguson, editors), pp. 159-179. Stanford: CSLI.

Croft, W. (1990) Typology and universals. Cambridge: Cambridge University Press.

De Benito Moreno, C. (in revision) Passivity and impersonality: trespassing borders in Romance. In Argument structure in flux: the Naples/Capri papers (E. Van Gelderen, M. Cennamo \& J. Barðdal, editors). Amsterdam/Philadelphia: John Benjamins.

De Mello, G. (2005) Pasiva pronominal con referencia a cosa: 'He puesto esta revista aquí para que se la lea', Hispanic Journal 26, 9-20.

Fernández Lagunilla, M. (1975) Acerca de la secuencia 'se impersonal + enclítico de $3^{a}$ persona': ¿una restricción superficial?, Revista de la Sociedad Lingüística Española 1, 177-193. 
Fernández-Ordóñez, I. (1990) Corpus Oral y Sonoro del Español Rural. (www.uam.es/coser)

Fernández-Ordóñez, I. (1999) Leísmo, laísmo y loísmo. In Gramática Descriptiva de la Lengua Española (I. Bosque \& V. Demonte, editors), pp. 1317-1397. Madrid: Espasa.

Fernández-Ordóñez, I. (in press): Dialect areas and linguistic change: Pronominal paradigms in Ibero-Romance dialects from a cross-linguistic and social typology perspective. In Dialects as a testing ground for theories of language change (G. Vogealaer \& G. Seiler, editors). Amsterdam/Philadelphia: John Benjamins.

Fernández Soriano, O. (1993) Los pronombres átonos. Madrid: Taurus.

Fernández Soriano, O. (1999) El pronombre personal. Formas y distribución. Pronombres átonos y tónicos. In Gramática Descriptiva de la Lengua Española (I. Bosque \& V. Demonte, editors), pp. 1209-1273. Madrid: Espasa.

Givón, T. (2001) Syntax. Amsterdam: John Benjamins.

Laca, B. (2006) El objeto directo. La marcación preposicional. In Sintaxis histórica de la lengua española. Primera parte: La frase verbal (C. Company, editor), pp. 423-478. México: Fondo de Cultura Económica / UNAM.

Mendikoetxea, A. (1999) Las construcciones con se. In Gramática Descriptiva de la Lengua Española (I. Bosque \& V. Demonte, editors), pp. 1631-1722. Madrid: Espasa.

RAE (2009) Nueva gramatica de la lengua española. Madrid: Espasa.

Rodríguez Molina, J. (2010) La gramaticalización de los tiempos compuestos en español antiguo, doctoral thesis. Madrid: UAM.

Santiago, R. (1957) 'Impersonal' se le(s), se lo(s), se la(s), Boletín de la Real Academia Española 55, 83-107.

Schwenter, S. A. (2006) Null objects across South America. In Selected Proceedings of the 8th Hispanic Linguistic Symposium (T. L. Face \& C. A. Klee, editors), pp. 23-36. Somerville, MA: Cascadilla Proceedings Project.

Studerus, Lernard (1984) Impersonal $s e+l o(s)$, la(s): a tentative regional profile, Southwest Journal of Linguistics 7, 57-68.

Carlota de Benito Moreno

Universidad Autónoma de Madrid

carlota.benito@titulado.uam.es 